\title{
News, Notes and Queries BURNS' HOUSE AND THE
DIRECTORS OF DUMFRIES AND GALLOWAY ROYAL INFIRMARY
}

'Is there a Bard of rustic song,

Who, noteless, steals the crowds among,

That weekly this aréa throng?-

$\mathrm{O}$, pass not by!

But with a frater-feeling strong,

Here, heave a sigh.'

THE Royal Burgh of Dumfries has much to occupy those interested in the life of Robert Burns. During his tenancy of Ellisland Farm, six miles from Dumfries, the poet was a frequent visitor to the town. On 4 June 1787, two months after publication of the second edition of his poems, he was admitted burgess of the Burgh. Later, at Martinmas, 1791, he took up permanent residence in Dumfries with his wife, Jean Armour, and their three children, Robert, Francis and William, and in this town passed the remaining years of his life. After occupying three small rooms in the Wee Vennel (now Bank Street), he moved to a house in Millbrae Vennel (now Burns Street), where he died in 1796. Jean Armour, with their children, continued to dwell there until her death thirty-eight years later.

Although much has been written regarding Burns' illnesses, there is no record of his having attended Dumfries and Galloway Infirmary (later Royal Infirmary) at any time, a surprising fact when one recalls that the years spent in the Burgh were times of chronic ill-health. Despite the apparent absence of any association during his lifetime with the Infirmary, a posthumous connection developed when the Directors of the latter Institution acquired the poet's residence.

Some fifty years after the death of Robert Burns, his son, Colonel William Nicol Burns, purchased the house once rented to the poet, together with adjoining property, with the object of establishing a memorial to the bard. For several years Colonel Burns let the House and neighbouring weaving shop to the Dumfries and Maxwelltown Education Society at an annual rent of $£ 15$, the house being used as a teacher's residence and the weaving shop as a classroom in connection with a Ragged School conducted by that Society. In 1858, by two dispositions dated 18 June of that year, Colonel Burns conveyed to the Education Society Burns' House and other premises. If, however, that Society ceased to exist or to maintain within the Burgh a Ragged School or other similar Charitable Educational Institution, then the property was to go to the Directors of Dumfries and Galloway Royal Infirmary or their successors in office.

I, COLONEL WILLIAM NICOL BURNS, late of the Honble. the East India Company's Service, now residing in Cheltenham, CONSIDERING that I several years ago acquired certain Subjects situated in Burns Street, Dumfries, including the Dwellinghouse in which my Father, Robert Burns, Poet, lived for some years prior to his death and in which he died, and that I am desirous of providing for the proper maintenance and keeping in repair of the said Dwellinghouse after my decease, as forming an interesting relic connected with my Father's memory, and also for the maintenance and keeping in repair the Mausoleum erected to his memory in Saint Michael's Churchyard of Dumfries, and within which the mortal remains of the Poet and of his Wife (my Mother) Jean Armour, as well as some other members of the family are 


\section{News, Notes and Queries}

interred: AND FARTHER CONSIDERING that these objects may be best accomplished by conveying the said Dwellinghouse and others to some Public Body or Institution of a permanent character, and seeing that the Dumfries and Maxwelltown Education Society is now and has for some years past been in possession of said Dwellinghouse and of certain adjoining premises and that I am desirous that said Society should continue in possession thereof, and thus in some degree associate the memory of the Poet with that Charitable and Philanthropic Institution: THEREFORE and for other good causes and considerations I have given, granted and disponed, as I do hereby (but always with and under the real liens and burdens after specified) GIVE, GRANT, CONVEY, ALIENATE, and DISPONE from me, my heirs and successors to and in favour of the said Dumfries and Maxwelltown Education Society. for the use and behoof and for the purposes of the said Society so long as the said continues to exist as after mentioned, and in the event of the said Society ceasing to exist or ceasing to maintain within the boundary of Dumfries a Ragged School or other similar Charitable Educational Institution in an efficient state (the question of such efficiency or non efficiency should it arise to be determined by the Sheriff of Dumfries-shire for the time being) then and in that event to and in favour of The Dumfries and Galloway Royal Infirmary and of the Office Bearers thereof for the time being and their successors in office, for the use and behoof and for the purposes of that Institution, All and Whole that Dwellinghouse lying on the East or North East side of Burns Street, Dumfries, now known as 'Burns House' ...

The Dumfries and Maxwelltown Education Society, and later the Dumfries and Maxwelltown Industrial School Trustees, administered the Trust for many years until, owing to a change in their location, they were unable to fulfil its conditions. As a result, the Trust devolved upon the Directors of the Dumfries and Galloway Royal Infirmary.

The Directors had no knowledge of the existence of the Disposition or of its contents until the beginning of June 1931, when there came into their hands a copy of a draft note of objections which the Education Society proposed lodging with the Education Endowments Commissioners, who, under the Education Endowments (Scotland) Act, 1928, were about to formulate a scheme for the management and government of the Society and its endowments. On approaching the Secretary of the Education Society, the Directors of the Infirmary discovered that they were indeed substitute disponees and, therefore, entitled to supersede the Society. At the same time, they learned that the Dumfries and Maxwelltown Education Society was negotiating with the Town Council of the Burgh of Dumfries and the Dumfries Burns Club with a view to handing over Burns' House to a Trust which would deal with all the relics and memorials of Robert Burns in the neighbourhood. Representation to the Educational Endowments Commissioners resulted in the claims of the Infirmary against the scheme being sustained.

In answer to further demands from the Royal Infirmary, the Secretary of the Education Society surrendered a copy of the Disposition. For the first time the Directors appreciated that this document contained much larger subjects than Burns' House and that, moreover, the Dumfries and Maxwelltown Education Society had not satisfied the conditions of the Trust since 15 May 1925, from which date they had failed to maintain within the boundary of Dumfries 'a Ragged School or other similar Charitable Institution'. Eventually, in May 1934, the Infirmary gained possession not only of Burns' House, other premises in Burns Street and Burns' Mausoleum but also of a capital sum of $£ 92210$ s. $0 d$. and interest on that capital sum since 1925 amounting to $£ 41610$ s. $4 d$.

The Infirmary's claim to the poet's dwelling was the subject of heated debate in 


\title{
News, Notes and Queries
}

the Council Chambers and of critical comment in the local press. The editor of the Dumfries and Galloway Standard (27 January 1934) considered the custody of memorials to be 'a somewhat odd sideline of Infirmary administration':

\begin{abstract}
THE BURNS PLACES.
The guarded statement made by ex-Provost Brodie at the annual meeting of Dumfries Infirmary on Thursday about the Burns Places does not carry us very far along the road to a settlement of the problem. The historical statement as to the legal difficulty arising out of the want of a proper title is an awkward snag. But assuming that this is got over, what then? Mr. Brodie left the meeting in no doubt as to his intention to undertake the responsibility laid on the Infirmary under the disposition of Colonel Burns. It seems a somewhat odd sideline of Infirmary administration, but if the Infirmary stands on its rights, there is nothing further to be done, and we can only hope that the Infirmary Directors will take steps to end the state of affairs at the Mausoleum which has caused so much adverse criticism. By their success in dealing with this matter they will be judged by the wider public outside the area of the Infirmary's operations.
\end{abstract}

The Directors accepted their new charge responsibly and determined to restore the house by decoration and furnishing to that of the Burns period. Several items of furniture were gifted and a considerable number of relics were presented or loaned for display in the building. A Burns' House Trust Committee was set up to deal with the restoration, administration and publicity arrangements. A scheme of improvement was soon under way; the cement facing on the front wall was stripped off and the joints picked out and repointed. Papers on the interior walls and ceilings were removed and the plaster work repaired. A modern kitchen range was replaced by the firebars and swey of an earlier generation while, in the sitting-room, the fireplace was removed to accommodate an older model.

A building opposite Burns' House was purchased from the Town Council and adapted for use as a dwelling for the caretaker. Hitherto the custodian's family had occupied the poet's house, an arrangement which permitted visitors to view only the room in which the Bard died.

On 25 January 1935, on the 176th anniversary of the poet's birth, the house was reopened to the public. To Miss Jean Armour Burns Brown, great-grand-daughter of Robert Burns, fell the honour of opening the door. During the ceremony, which was broadcast by arrangement with the British Broadcasting Corporation, the late exProvost David Brodie, Chairman of the Board of Directors of the Infirmary, gave a brief outline of the devious legal channels by which the building had come under their administration.

The editor of the Dumfries and Galloway Standard (26 January 1935) was no longer in any doubt concerning the Infirmary's ability to administer such a memorial and was quick to acknowledge the attempt by the Board of Directors to discharge faithfully the Trust committed to them:

The reproach against Dumfries in regard to the way in which the Burns' House and Mausoleum were kept has now been wiped out, to the great relief of the citizens who did not know and who could not understand the reason for the delay. Yesterday afternoon Burns' House was formally reopened, after a very thorough process of restoration, and, as the proceedings were broadcast; what has been done will be known to a very large number of people, not only in Dumfries, but throughout Britain. The work has been thoroughly well done. Since they took over, the Directors of the Dumfries and Galloway Royal Infirmary set to work with right goodwill to discharge the trust committed to them in the bequest of Colonel Burns. The House has been restored to 


\title{
News, Notes and Queries
}

the appearance which it must have had in the days when it was tenanted by the most illustrious citizen of Dumfries. Such modernisation as has been deemed necessary has been done as unobtrusively as possible. It is to be hoped that this most intimate of the Burns places will be made the home of the most precious relics of the Poet.

The report of the Burns' House Trust Committee, contained in the Annual Report of the Directors of Dumfries and Galloway Royal Infirmary for 1936, indicated that the affairs of the House were being administered in a business-like fashion. An official handbook had been published and attempts were being made to attract the foreign tourist to the town. If the management at Burns Street left little to be desired, however, it is obvious from the same report that the Mausoleum at the Churchyard of St. Michael's was presenting its own problems:

\begin{abstract}
The Committee report that during the past year an extensive scheme of advertising the House has been carried out, chiefly in the United States and in the Colonies. One direct result of this scheme of advertising is that certain foreign travel agencies are contemplating organising new special motor tours through the South of Scotland, while in other cases, certain tours to Scotland which up to the present have omitted Dumfries in their itinerary propose arranging a diversion so as to include a visit to the town of Dumfries. It is hoped that this extensive scheme of advertising which has been carried out will have the effect of bringing a greater number of visitors to the House than ever before.

In last year's report reference was made to the obligations on the Directors regarding the maintenance of the fabric of the Mausoleum, and also to the fact that the Dumfries Burns Club had erected certain new statuary in the building. Since the Directors of the Infirmary assumed control of the House they have carried out the work of keeping the Mausoleum and the ground surrounding it in as neat and tidy condition as was possible, while their caretaker at Burns' House has also attended at the Mausoleum when asked by any visitors. For many years prior to the Infirmary Directors becoming Trustees of this Trust there existed a type of dual control of the Mausoleum, and it has been found that this arrangement was very unsatisfactory. The Committee is glad to be able to report that as a result of protracted negotiations with the Burns Club an arrangement has been come to whereby the Burns Club not only hold themselves responsible for the statuary within the Mausoleum but also for the maintenance of the Mausoleum itself, the liabilities of the Trustees being commuted to an annual payment to the Burns Club.
\end{abstract}

Over the course of the next few years several difficulties arose, not least among them being the friction between the Directors of the Infirmary and the Secretary of the Burns Club. The latter suggested repeatedly that the Directors could have no interest in the House and, therefore, it should be transferred to a body like the Dumfries Burns Club. The Directors, for their part, maintained that the Burns Club had no permanent constitution and might die at any time. Consequently, no Court of Law would recognise a scheme of transfer.

With the outbreak of war in 1939, the number of visitors to the House declined sharply and no longer justified keeping it open except during the summer months. At the meeting of the Burns' House Trustees held on 26 December 1941, therefore, it was resolved that for the duration of the war the building should be closed to visitors except during such periods as the Committee might from time to time determine.

The acceptance by the Board of this recommendation and its implementation resulted in representation from individuals who had made their pilgrimage to Burns' House, only to find the door closed. The matter also caused concern to the Town Council and on 22 February 1944, the Provost and Town Clerk of the Burgh met with 


\section{News, Notes and Queries}

the Burns' House Trust Committee to see if there was any way in which the Council could assist with improving the facilities. A general discussion ensued in the course of which the Provost stated that it was his personal opinion that the two buildings, Burns' House and the Mausoleum, being two objects of great public interest, ought to be owned and administered by the Town Council. After the withdrawal of the Provost and the Town Clerk, the meeting resolved that should any formal proposal be received from the Town Council to take over the running of Burns' House and the Mausoleum, on terms likely to be approved by the Court of Session, such a proposal should be considered favourably.

Later that year, on $17 \mathrm{July,} \mathrm{negotiations} \mathrm{were} \mathrm{completed} \mathrm{as} \mathrm{a} \mathrm{result} \mathrm{of} \mathrm{which} \mathrm{the}$ Town Council were vested as Trustees. In addition, the Infirmary sold to the Council for a capital sum of $£ 600$ its right to benefit from any profits made from the House.

\section{ACKNOWLEDGEMENT}

The author thanks Robert Dinwiddie \& Co. Ltd., Dumfries, for permission to reproduce the drawing of Burns' House.

\section{REFERENCES}

Dumfries and Galloway Royal Infirmary: Annual Report, 1936.

Dumfries and Galloway Standard, 27 January 1934.

Dumfries and Galloway Standard, 26 January 1935.

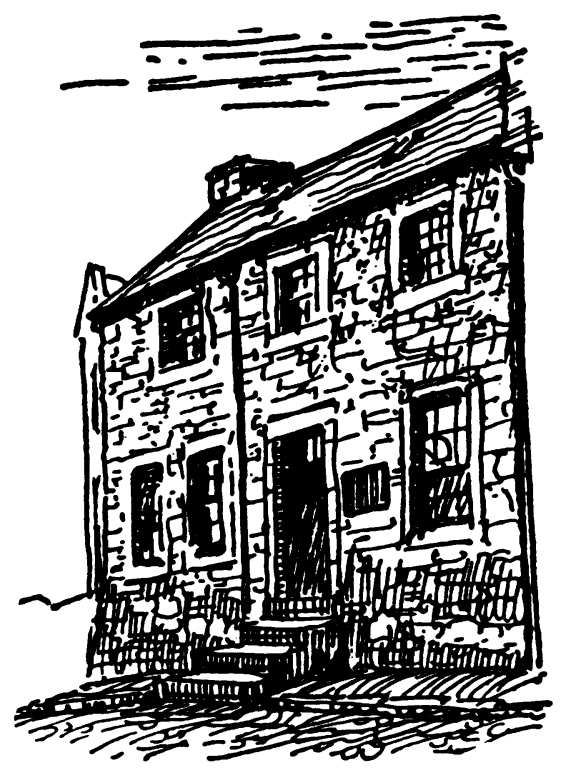

Burns' House: 'A somewhat odd side-line of Infirmary administration' (Dumfries and Galloway Standard, 27 January 1934).

THOMAS W. BAILLIE 